\title{
Fire is REDD+: offsetting carbon through early burning activities in south-eastern Tanzania
}

\author{
Kaysara Khatun, Esteve Corbera and Steve Ball
}

\begin{abstract}
A project combining participatory forest management and REDD+ (Reducing Emissions from Deforestation and forest Degradation) is underway in south-eastern Tanzania. It introduces early burning practices to reduce the number and (heat) intensity of wild and late-season fires, to develop robust carbon accounting methods. Our analysis considers the causes of forest fires, and local people's knowledge of the early burning process and its impacts on livelihoods, through the development of early burning activities as a potential source of carbon revenue. Some of the difficulties of implementation have been resolved over time (e.g. the premature introduction of carbon contracts), whereas others remain: there are inequalities in knowledge, awareness and participation in early burning and the broader REDD+ process at village level. A more structured approach to early burning, with well-publicized advance planning, that includes all community members and subvillages would make a significant difference. Further challenges exist in the form of both legal and illegal hunting, a cause of forest fires that could undermine the early burning process. We argue that the long-term commitment of project managers to gain detailed knowledge of social-ecological systems, forest governance and local politics is required to successfully develop this and other similar REDD+ projects.
\end{abstract}

Keywords Carbon, fire management, livelihoods, participatory forest management, REDD+, Tanzania

\section{Introduction}

- orest conservation and management activities provide opportunities to reduce the levels of carbon dioxide in the atmosphere by sequestering it in soils and vegetation (Khatun et al., 2010). In many regions, however, fire is an important threat to the success of such activities because it can suppress tree growth and biomass, increase the mortality of large trees and trigger an irreversible cascade of

Kaysara Khatun (Corresponding author) Instituto de Altos Estudios Nacionales, Centro de Prospectiva Estratégica, Quito, Ecuador

E-mail kaysara1@gmail.com

Esteve Corbera Institute of Environmental Science and Technology \& Department of Economics and Economic History, Universitat Autònoma de Barcelona, Bellaterra, Spain

Steve Ball Technical Department, Mpingo Conservation and Development Initiative, Kilwa Masoko, United Republic of Tanzania

Received 8 July 2015. Revision requested 28 September 2015.

Accepted 19 January 2016. First published online 13 May 2016. biodiversity loss, with a complete turnover of species composition, affecting both the functioning and ecology of a biome (Barlow et al., 2012). Fire is a pre-eminent tool for managing ecosystems for human use, and prescribed burning is commonly used, particularly in tropical and subtropical regions, to maintain pastures and woodlands, prepare crop fields, control pests and manage wildfires (Kull, 2002; Van Lear et al., 2005). It is therefore an important strategy for conservation and natural resource management, particularly in forests and ecosystems prone to fire-related disturbances (Haines et al., 1998), and controlled burning is often recommended to reduce the extent or intensity of forest fires (e.g. Laris, 2011). Anthropogenic burning regimes buffer savannah and forest, maintaining ecological stability (Laris et al., 2015); they can thus be considered to be a social-ecological phenomenon connecting cultural and resource management practices with vegetation types.

The governance of forest fire in the tropics has moved beyond the territorial concerns of states and taken on a more global dimension, driven by concerns about transboundary pollution (e.g. Forsyth, 2014) and, in particular, the need for climate change mitigation. This is exemplified in the UN framework initiative for Reducing Emissions from Deforestation and forest Degradation, and enhancing and sustainably managing carbon stocks (REDD+). REDD+ commonly regards slash-and-burn practices and prescribed burning activities as central to the development of national land-use mitigation strategies and localized pilot projects, particularly in regions where fire plays a key role in land-use change (Barlow et al., 2012). It has been proposed that savannah fire management regimes could combine customary fire management practices with modern management techniques to reduce greenhouse gas emissions and thus be eligible to profit from the production of carbon offsets (Russell-Smith et al., 2013).

We present research into the initial implementation of early burning (a form of prescribed burning) as a means to deliver carbon offsets in a REDD+ pilot project in Tanzania. The project is led by a local NGO, the Mpingo Conservation and Development Initiative, and supported by the Norwegian government. It combines participatory forest management with early burning to reduce the loss of carbon from more intensive forest fires and to generate revenue for the local communities through the sale of certified timber and carbon offsets. The project differs from fire disciplining efforts primarily because it does not attempt to prevent the use of fire by farmers. Rather, it encourages collectively managed early burning practices around village 
forests to reduce the likelihood of more intense fires at the peak of the dry season. It is expected to generate revenues that more than compensate for the time communities invest in these new fire management activities.

Few empirical studies have addressed fire specifically as a degradation problem relevant to REDD+ in Africa (Bozmoski \& Hultman, 2010; Burgess et al., 2010; Peskett et al., 2011; Minang \& van Noordwijk, 2013) or elsewhere (e.g. Aragão \& Shimabukuro, 2010; Barlow et al., 2012; Müller et al., 2013), and none have featured fire management as a potential source of carbon offsets or examined the subsequent implications for local livelihoods. We present a critical assessment of the initiative in Tanzania, focusing on four pivotal issues: (1) the causes of forest fires, which reflect peoples' burning practices; (2) the awareness and knowledge local people have of the project and its activities; (3) the impacts of early burning activities on people's livelihoods; and (4) the technical implementation and challenges of the project. Most fires in savannahs and dry forests are started by people, and therefore a comprehensive understanding of the traditional uses of fire has to be a precursor to community cooperation in fire management strategies (Kull \& Laris, 2009). We thus illustrate the realities of village life, taking into account the evolving nature of the project, and assess the viability of fire management efforts in the context of REDD+.

\section{The REDD+ pilot project in Kilwa District}

\section{Project description and data collection}

The Mpingo Conservation and Development Initiative project is located in the coastal district of Kilwa, which covers 13,347.5 $\mathrm{km}^{2}$ and is one of Tanzania's most densely forested districts (Miya et al., 2012). The forests in central Kilwa are a mix of miombo woodlands and patches of East African Coastal Forests, forming a complex mosaic that covers c. $70 \%$ of the land. Approximately $85 \%$ of Kilwa's population is rural and dependent on natural resources for their livelihoods (National Bureau of Statistics, 2013).

The NGO's work is focused on participatory forest management and in particular the sustainable management of precious local hardwood timbers, including East African blackwood Dalbergia melanoxylon (known locally as mpingo). Participatory forest management acts as a basic legal facilitator for REDD+ as it gives communities control and ownership of their local forest resources (including timber) through demarcated village land forest reserves, which would otherwise be controlled by the government (URT, 2007). The village forests in Kilwa supported by the Mpingo Conservation and Development Initiative are relatively extensive woodlands, typically at a distance from villages, and had not been utilized previously by local people

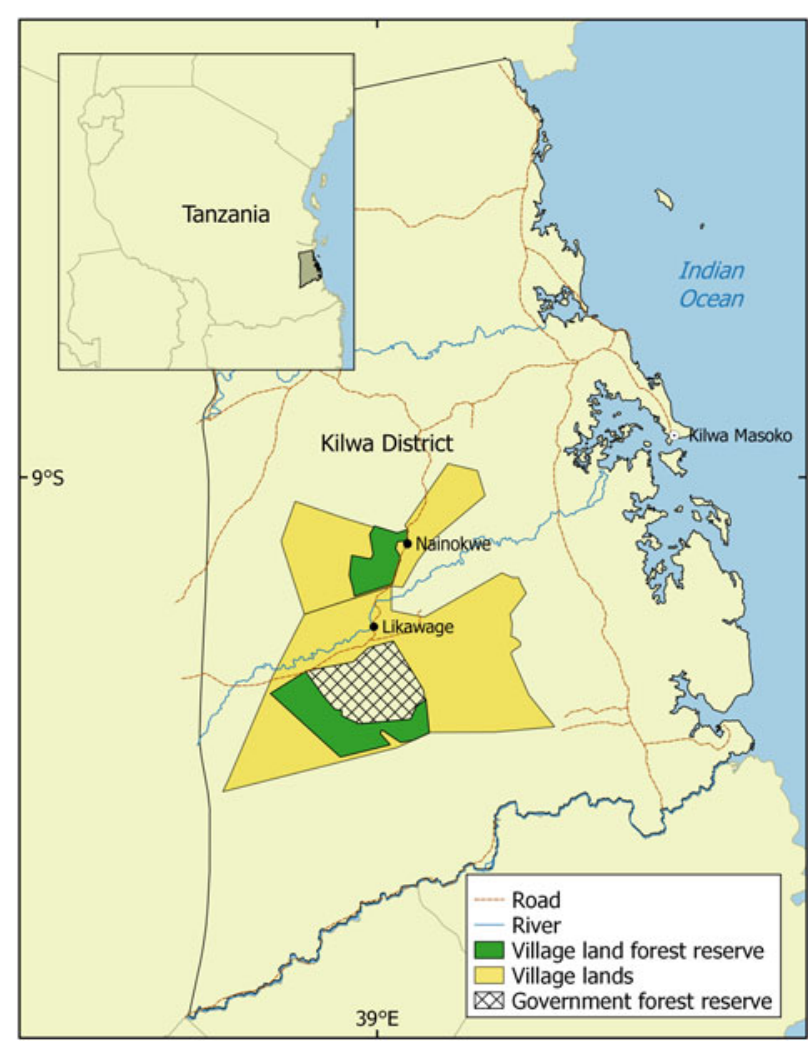

FIG. 1 Location of the Mpingo Conservation and Development Initiative's REDD+ project in Kilwa District, Tanzania.

TABLE 1 Estimated carbon losses in Kilwa District, Tanzania (Fig. 1) as a result of deforestation caused by timber harvesting, charcoal production, agricultural activity and fire (adapted from Miya et al., 2012, p. 28).

\begin{tabular}{lrrrr}
\hline & \multicolumn{2}{c}{ Carbon loss (t per year) } & \\
\cline { 2 - 4 } $\begin{array}{l}\text { Driver of } \\
\text { deforestation }\end{array}$ & Minimum & \multicolumn{1}{c}{ Best } \\
guess & Maximum & $\begin{array}{c}\text { of } \\
\text { total }\end{array}$ \\
\hline Timber & 12,000 & 28,000 & 64,000 & 19 \\
Charcoal & 2,000 & 4,000 & 9,000 & 3 \\
Agriculture & 20,000 & 44,000 & 93,000 & 29 \\
Fire & 0 & 74,000 & 450,000 & 49 \\
Total & 34,000 & 150,000 & 616,000 & 100 \\
\hline
\end{tabular}

(Fig. 1). The main drivers of deforestation and forest degradation in Kilwa District (and across most miombo woodlands in southern Africa) are the demand for timber and charcoal, land clearing for agriculture, and both human-induced and wild fires. Table 1 presents the estimated carbon losses associated with each driver for the Kilwa region.

The development of early burning activities is a new addition to participatory forest management in Tanzania, and the Mpingo Conservation and Development Initiative expects it to deliver a complementary revenue stream for communities from the sale of voluntary carbon offsets. Although the early burning trials reported here were relatively small in magnitude, 
TABLE 2 Details of the study villages and subvillages in Kilwa District, Tanzania (Fig. 1), with population, name of village land forest reserve and date established, size of reserve, and distance of subvillages to the main village and to the reserve.

\begin{tabular}{llllll}
\hline Village/Subvillage & Population & $\begin{array}{l}\text { Name of reserve } \\
\text { (date established) }\end{array}$ & $\begin{array}{l}\text { Size of } \\
\text { reserve (ha) }\end{array}$ & $\begin{array}{l}\text { Distance from } \\
\text { main village* }(\mathrm{km})\end{array}$ & $\begin{array}{l}\text { Distance to } \\
\text { reserve* }(\mathrm{km})\end{array}$ \\
\hline Likawage & 2,035 & Long'ou (2011) & 17,921 & 0 & 22 \\
$\quad$ Nunjumba & 1,879 & & & 9 & 31 \\
Kinaki & 783 & & & 3 & 25 \\
$\quad$ Gogozembe & 1,315 & Kijawa-Miti (2008) & 8,047 & 5 & 0.6 \\
Nainokwe & 540 & & & 0 & 7 \\
$\quad$ Kichonda & 120 & & & 19 \\
\hline
\end{tabular}

${ }^{*}$ By road

when scaled up to all the forests in Kilwa District currently under community management with support from the Initiative c. 10,000 ha will need to be burned per week to meet the target of $35-40 \%$ of the forest being burned early in the dry season. Timing early burning efforts over the transition from the wet to dry season is critical to constrain fire intensity (which increases later in the dry season as the drier grasses act as fuel; Laris, 2011). Around Kilwa the dry season is usually June-November, with peak rainfall in April and May.

Of the 10 villages in which the Mpingo Conservation and Development Initiative was active only five had substantially implemented early burning; we focus on two of these, along with their sub-villages (Table 2). Nainokwe has been supported by the Initiative since 2008, and early burning was trialled there for the first time in 2012 and repeated in 2013. Each trial lasted $<_{1}$ month and the costs were covered by timber sales. Likawage has been supported since 2011 and is the main site for testing and development of the project's fire management protocols. Early burning was introduced there in 2012 but was not implemented fully until 2013. Larger areas of forest were burned, early burning took longer to carry out (2 months; May-June 2013) and costs were covered by the Mpingo Conservation and Development Initiative.

\section{Measuring carbon impacts}

Planning is important to the success of early burning and to ensure the most vulnerable parts of the forest are adequately protected. All forest boundaries should be burned, as should both sides of every path and track that passes through the forest. Areas of the forest where the topography results in frequent fires require particular attention. This is a costly endeavour, and therefore an economic feasibility study was commissioned, which found that the project was viable at a carbon price of USD 5 per tonne as long as the main initial investment costs were borne by a donor (Fehse, 2012).

A reduction in the number of fires is just one of a number of steps required for early burning to succeed with REDD+; the carbon saved from fire management activities must also be quantified. Carbon impacts are calculated using the computer model GapFire (Ryan \& Williams, 2011), which has been customized according to the requirements of the REDD+ project. GapFire is a dynamic model of forest biomass constructed to simulate the impacts of a variety of fire regimes on the structure of miombo woodlands, where the gaps are the openings in the canopy that are created when trees die (Bowers \& Williams, 2013). By explicitly modelling the growth, mortality and regeneration of trees at these forest gaps the model can predict the balance between carbon sequestration through forest regrowth and carbon emissions from woodland disturbance (Bowers \& Williams, 2013). The Mpingo Conservation and Development Initiative intends to sell carbon offsets derived from early burning for $\geq$ USD 5 per tonne of carbon dioxide equivalent through voluntary carbon markets. This could generate additional revenue of up to USD 250,000 per year per village (depending on the size of the forest). As there was no existing methodology dealing with the effects of fire on dryland forests, a new methodology was devised to quantify potential carbon savings. The methodology (VMoo29, Fehse \& Ball, 2014) was approved by the Verified Carbon Standard in May 2015.

The computation of carbon offsets is based on the GapFire model's estimation of regular late season fires, which would lead to annual carbon losses of c. 0.4 tonnes of carbon per ha. If this loss can be prevented or partly prevented by early burning activities then the difference in carbon stored in the forest between the baseline and project scenarios can be sold (Fig. 2b). The model predicts, for example, that over a 20-year period the project would avoid emissions and increase carbon capture amounting to c. 10 tonnes of carbon per ha.

\section{Methods}

We studied the Mpingo Conservation and Development Initiative's documents, semi-structured interviews, and household data from 2011 and 2014 (Corbera et al., 2015) to explore the implications of early burning activities for project management and community livelihoods. The lead author interviewed three of the NGO's staff members. At 

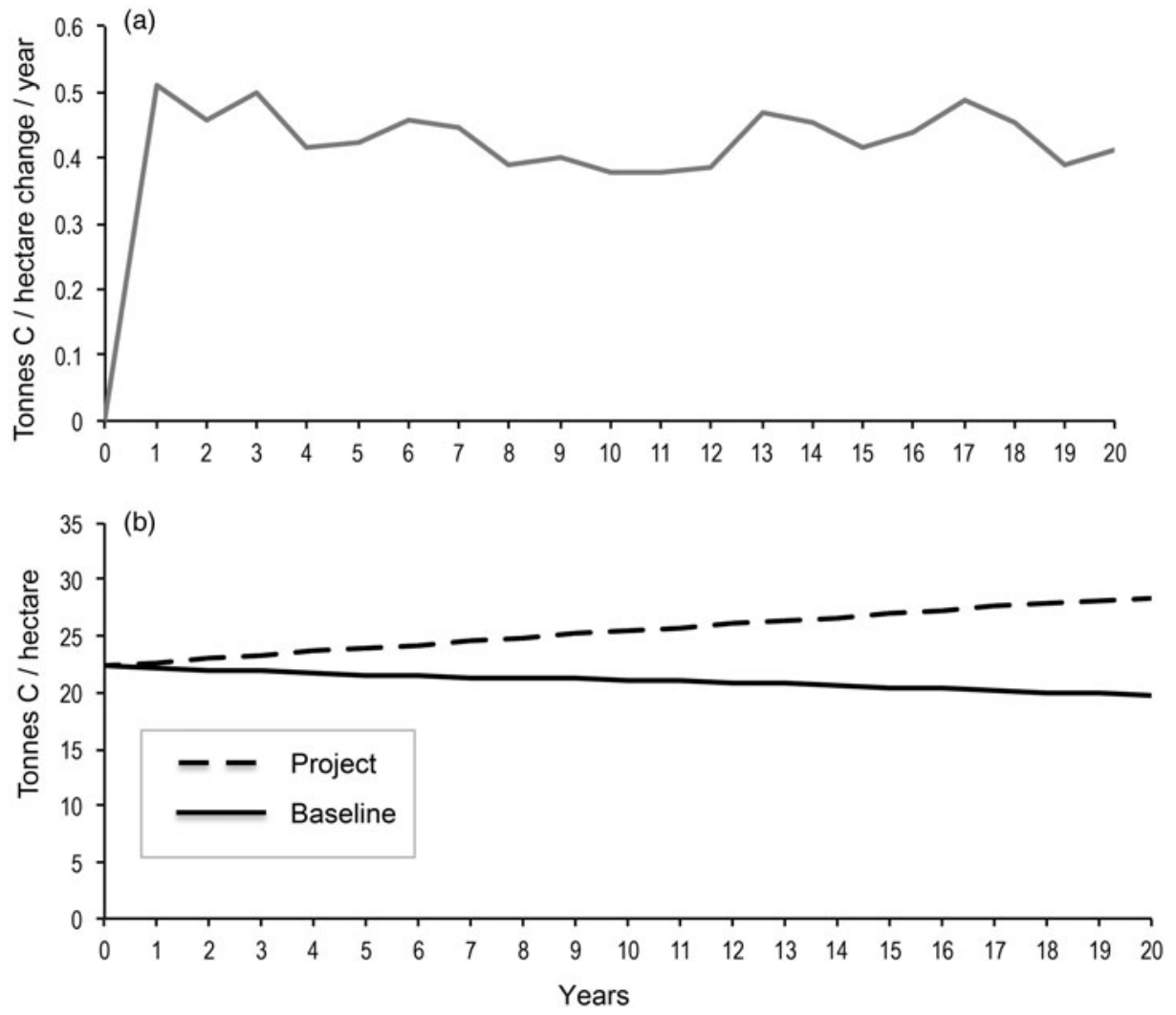

FIG. 2 (a) Modelled annual net changes in carbon storage as a result of the Mpingo Conservation and Development Initiative's REDD+ project in Kilwa District, Tanzania (Fig. 1), from the beginning of fire management by early burning in Year 1. (b) Overall changes in carbon storage in baseline and project scenarios from the beginning of fire management by early burning in Year 1, according to the GapFire model. The number of years pertain to a theoretical project implementation (starting at any Year 1), as funding has not yet been secured to extend the pilot work discussed here into a full-scale Verified Carbon Standard-validated project. village level 34 in-depth interviews (each c. 2 hours) were conducted with community members (22 men and 12 women) as part of this study, with a similar number of interviews carried out in Nainokwe and Likawage and their subvillages. The interviewees were purposively chosen from a list of households, categorized according to wealth (rich, medium or poor), which had been produced through village-level focus group exercises in 2011, using material assets as a proxy for wealth. Interviewees included members of the Village Natural Resources Committees, three people who utilized fire for their livelihoods (a beekeeper, a charcoal maker and a pastoralist), and other local people distributed across the three wealth categories.

In the outlying subvillages (one in Nainokwe and three in Likawage) we surveyed 36 community members by means of a simple questionnaire to assess local knowledge of forest reserves, early burning and REDD+, and to triangulate information obtained from the interviews and project documentation. Responses were categorized according to whether the interviewee was aware of the demarcated forest reserves or of any of the Mpingo Conservation and Development Initiative's other activities, and particularly of early burning and REDD+. Of those who were aware, we asked if they were able to make the connection between project activities and REDD+, why early burning was done and if it was related to REDD+. For those who had not heard of the project and the subsequent activities, we explained the process to them and asked how they thought the project would affect livelihoods and how effective it was likely to be, and what they thought of the selection process for early burning.

\section{Results}

Burning landscapes: fire usage and causes of wildfire

From stakeholder interviews in the two study villages we confirmed that all community members use fire in their daily lives, including for cooking, heating and for agricultural land clearing and preparation. In reduced visibility most local people light fires when walking through the forest, to reduce the risk of encounters with wildlife. Hunters also use fire to encourage new grass growth, both to attract wildlife and facilitate access to the forest by motor vehicle. Thus fire is typically used by local people in two broad ways: controlled burning of small areas to clear vegetation for farming or to create fire-breaks, and uncontrolled burning, where little or no attempt is made to restrict the spread of fire (e.g. when fire is used to increase visibility in the forest).

Interviewees generally indicated that past, uncontrolled forest fires were not caused by domestic activity, and were rarely attributable to farm preparation. They indicated that the areas most vulnerable to fire were those where there was human traffic (e.g. along tracks to farms and neighbouring villages, and paths running through or adjacent to the forests). Open areas close to forests were also perceived as being vulnerable to fires, especially where there are tall grasses (e.g. above head height). These areas 
are prone to high-intensity fires earlier in the dry season than are other areas. Deliberate arson was rare and was deemed more likely to occur in forests further from the main village and subvillages.

Most interviewees believed that both illegal and legal hunters were probably responsible for the majority of fires in the forest reserves. Legal commercial hunters are always from outside the communities, have a government permit, and hunt for trophies. In contrast, illegal hunters may be from the local community or neighbouring villages and towns, hunt for game meat that can be sold, and use a variety of traps and snares. Hunting block concessions are located in and around the studied communities and administered by the Wildlife Division of the Ministry of Natural Resources \& Tourism. Lighting fires for hunting is not allowed under Tanzanian law but in remote areas there is often no enforcement of the law. For this reason, both the Mpingo Conservation and Development Initiative and local people agreed that hunting is an important but difficult problem to solve. People cited lack of power and control, and suggested that the best way forward would be to strengthen cooperation between the villages and the District Council through the REDD+ project, as commercial game hunting is managed by the government. However, it is the opinion of Mpingo Conservation and Development Initiative personnel that early burning will resolve the problem of illegal fires to a considerable degree, as visibility will already be established in areas where early burning has been carried out, and these areas of pre-burnt vegetation will constrain the spread of other fires lit by hunters. Most interviewees were optimistic that increased awareness and the financial benefits gained from the REDD+ project would make it more difficult for local illegal hunters to peddle their wares in their own communities or in nearby villages.

\section{Knowledge and awareness of early burning and its implications for livelihoods}

Interview responses indicated that most community members were aware of the demarcated village forest reserve, early burning and REDD+, as well as the connection between the latter two (Table 3). Everyone interviewed in Nainokwe was aware that village land was set aside for early burning activities and the REDD+ project, and some understood why early burning was carried out 'when grass is half wet and half dry, to prevent fire'. The results from the interviews in Nainokwe and its subvillage Kichonda are in Table 3. Interviewees included members of the village natural resource council as well as other community members.

In Likawage and its subvillages only one person had not heard of the village land forest reserve, more people were aware of early burning than REDD+, and only three people could identify the connection between the latter two
(Table 3). The findings of the short surveys carried out in 2014 are consistent with those of surveys carried out in 2011 and 2014 by Corbera et al. (2015). The results are compared in Table 4 .

In general, men were more informed than women regarding early burning and the village land forest reserve but more women in both Nainokwe and Likawage knew about early burning compared to household panel data from 2011 and 2014 (Corbera et al., 2015). However, although overall knowledge of early burning increased, awareness of the village land forest reserve in Likawage declined between 2011 and 2014 (both in this study and in Corbera et al., 2015) among both men and women.

The interview data show that the learning process about project activities in both villages was uneven across gender, wealth and subvillages. Understanding of REDD+ was poor across the range of interviewees and was linked to participation in the Village Natural Resources Committee. Women on the committee knew about the village forest and early burning and expressed opinions about early burning and other activities in the forest reserve, in contrast with those who were not on the committee. In Nainokwe people were more engaged with the participatory forest management process and more aware of activities in the reserve in general compared to Likawage, where many people were unaware of the existence of the forest reserve. Forest activities have a smaller role in village life in Likawage, whereas people in Nainokwe have already earned revenue from their forest.

\section{Implications of early burning for livelihoods}

By implementing early burning, communities can become directly involved in management of the forest reserve and can earn money as a result. According to our interview data community members in subvillages are less involved in early burning activities than those in the main villages. Although Nainokwe has benefitted from the project, gaining a house for its village executive officer as well as fees for early burning (see Khatun et al., 2015, for more detail on benefits and conflicts), residents of the subvillage Kichonda, $19 \mathrm{~km}$ away, expressed frustration at their lack of involvement and inability to earn money from participating in early burning and other project activities. They complained that they received information about village affairs only through hearsay and not by any formal process:

There is conflict (between the outlying hamlet and the main village) not only because of early burning but also because of the revenue they receive from the forest. . .community members did not participate (in early burning) because they (the main village) have isolated and abandoned us. (Former village council member, Kichonda)

In Likawage and its subvillages, village leaders went door-to-door recruiting people for early burning activities. Four low-wealth interviewees said the method of selection 
TABLE 3 Summary of interview data from Likawage and Nainokwe villages and subvillages in Kilwa District, Tanzania (Fig. 1), with number of interviewees (according to sex and occupation), and their knowledge of the village land forest reserve, early burning and REDD+.

\begin{tabular}{|c|c|c|c|c|c|c|c|c|}
\hline \multirow{2}{*}{$\begin{array}{l}\text { Village/ } \\
\text { Subvillage }\end{array}$} & \multicolumn{2}{|c|}{ No. of interviewees (Occupation) } & \multicolumn{2}{|c|}{$\begin{array}{l}\text { No. with knowledge of reserve (Wealth } \\
\text { category) }\end{array}$} & \multicolumn{2}{|c|}{$\begin{array}{l}\text { No. with knowledge of early burning } \\
\text { (Wealth category) }\end{array}$} & \multicolumn{2}{|c|}{$\begin{array}{l}\text { No. with knowledge of REDD+ } \\
\text { (Wealth category) }\end{array}$} \\
\hline & Male & Female & Male & Female & Male & Female & Male & Female \\
\hline Likawage & $\begin{array}{l}7 \text { ( } 5 \text { farmers, } 1 \text { shop } \\
\text { owner, } 1 \text { employed in } \\
\text { local business) }\end{array}$ & $\begin{array}{l}4 \text { (2 farmers, } 1 \mathrm{~B} \& \mathrm{~B} \\
\text { owner, } 1 \text { restaurant } \\
\text { owner) }\end{array}$ & $\begin{array}{l}7 \text { ( } 3 \text { rich, } 1 \text { me- } \\
\text { dium, } 3 \text { poor })\end{array}$ & $\begin{array}{l}4(2 \text { rich, } 1 \text { me- } \\
\text { dium, } 1 \text { poor })\end{array}$ & $\begin{array}{l}6(3 \text { rich, } 1 \text { me- } \\
\text { dium, } 2 \text { poor })\end{array}$ & $\begin{array}{l}3 \text { ( } 2 \text { rich, } 1 \\
\text { medium })\end{array}$ & $\begin{array}{l}4 \text { ( } 2 \text { rich, } 1 \text { me- } \\
\text { dium, } 1 \text { poor })\end{array}$ & 1 (medium) \\
\hline Nunjumba & 2 (both farmers) & 1 (farmer) & $\begin{array}{l}2 \text { ( } 1 \text { medium, } 1 \\
\text { unknown) }\end{array}$ & 0 & $\begin{array}{l}2 \text { ( } 1 \text { medium, } 1 \\
\text { unknown) }\end{array}$ & 0 & $\begin{array}{l}2 \text { ( } 1 \text { medium, } 1 \\
\text { unknown) }\end{array}$ & 0 \\
\hline Kinaki & 2 (both farmers) & 0 & $\begin{array}{l}2(1 \text { rich, } 1 \\
\text { medium })\end{array}$ & & 1 (rich) & & $\begin{array}{l}2 \text { ( } 1 \text { medium, } 1 \\
\text { unknown) }\end{array}$ & \\
\hline Gogozembe & 0 & 2 (both farmers) & & $\begin{array}{l}2 \text { ( } 1 \text { medium, } 1 \\
\text { unknown) }\end{array}$ & & $\begin{array}{l}2 \text { ( } 1 \text { medium, } 1 \\
\text { unknown) }\end{array}$ & & 1 (unknown) \\
\hline Nainokwe & $\begin{array}{l}9 \text { ( } 5 \text { farmers, } 1 \text { farmer/ } \\
\text { carpenter, } 1 \text { bee-keeper, } 2 \\
\text { retired farmers) }\end{array}$ & $\begin{array}{l}4 \text { ( } 3 \text { farmers, } 1 \\
\text { charcoal maker) }\end{array}$ & $\begin{array}{l}9 \text { ( } 1 \text { rich, } 4 \text { me- } \\
\text { dium, } 2 \text { poor, } 2 \\
\text { unknown) }\end{array}$ & $\begin{array}{l}4 \text { ( } 1 \text { medium, } 2 \\
\text { poor, } 1 \\
\text { unknown) }\end{array}$ & $\begin{array}{l}8 \text { ( } 1 \text { rich, } 4 \text { me- } \\
\text { dium, } 1 \text { poor, } 2 \\
\text { unknown) }\end{array}$ & $\begin{array}{l}3 \text { ( } 1 \text { medium, } 1 \\
\text { poor, } 1 \\
\text { unknown) }\end{array}$ & $\begin{array}{l}4 \text { ( } 1 \text { rich, } 2 \text { me- } \\
\text { dium, } 1 \\
\text { unknown })\end{array}$ & $\begin{array}{l}2 \text { ( } 1 \text { medium, } 1 \\
\text { unknown) }\end{array}$ \\
\hline Kichonda & 1 (farmer) & 1 (farmer) & 1 (poor) & 1 (medium) & 1 (poor) & 0 & 0 & 0 \\
\hline Liwitie $^{2}$ & 1 (pastoralist) & 0 & 1 (unknown) & 0 & 1 (unknown) & 0 & 0 & 0 \\
\hline
\end{tabular}

${ }^{1}$ Seven interviewees participated in early burning activities ( 4 in Nainokwe, 1 in Likawage, 1 in Nunjumba, 1 in Gogozembe). One of these (a woman in Nainokwe) could connect early burning with REDD+, as could four men who did not practise early burning (1 in Nainokwe, 1 in Nunjumba, 2 in Likawage).

${ }^{2}$ There were no pastoralists residing in our case study villages, and therefore we included one who lived in Liwitie, who worked in Nainokwe and Liwitie. 
TABLE 4 Community awareness of the village land forest reserve and early burning activities as part of the REDD+ project in the villages of Likawage and Nainokwe (Fig. 1), based on household surveys in 2011 and 2014 (Corbera et al., 2015) and short surveys carried out in 2014 (this study).

\begin{tabular}{|c|c|c|c|c|c|c|}
\hline \multirow[b]{3}{*}{ Village } & \multicolumn{4}{|c|}{ Household survey $(n=50)$} & \multicolumn{2}{|c|}{ Short survey $(n=36)$} \\
\hline & \multicolumn{2}{|l|}{2011} & \multicolumn{2}{|l|}{2014} & \multicolumn{2}{|l|}{2014} \\
\hline & $\begin{array}{l}\text { Awareness of } \\
\text { reserve }(\%)\end{array}$ & $\begin{array}{l}\text { Awareness of early } \\
\text { burning (\%) }\end{array}$ & $\begin{array}{l}\text { Awareness of } \\
\text { reserve (\%) }\end{array}$ & $\begin{array}{l}\text { Awareness of early } \\
\text { burning (\%) }\end{array}$ & $\begin{array}{l}\text { Awareness of } \\
\text { reserve }(\%)\end{array}$ & $\begin{array}{l}\text { Awareness of early } \\
\text { burning (\%) }\end{array}$ \\
\hline \multicolumn{7}{|l|}{ Nainokwe } \\
\hline Men & 100 & 72 & 100 & 60 & 100 & 75 \\
\hline Women & 100 & 0 & 100 & 0 & 100 & 25 \\
\hline \multicolumn{7}{|l|}{ Likawage } \\
\hline Men & 100 & 9 & 86 & 32 & 86 & 57 \\
\hline Women & 83 & 17 & 80 & 10 & 75 & 40 \\
\hline
\end{tabular}

was not fair because they were not made aware prior to the event to arrange their availability. Some people participated in early burning more than once, receiving day wages two or three times. According to project staff the involvement of local people in early burning has improved in the villages that had already made money from timber sales and invested in village development projects (Khatun et al., 2015). Interviewees indicated a willingness to cooperate with the project and adjust their fire-related practices accordingly, acknowledging the direct and indirect benefits they could receive.

\section{Standardizing and selling carbon}

According to project staff, negotiating carbon contracts with landowners and rural communities has been challenging. During the first 2 years of the project they proposed a contract to regulate the terms and conditions for both participatory forest management and any future carbon offsets from the demarcated forests. The contract contained a description of the area, the forest products and ecosystem services within the reserve, and who held the rights to these. The seven-page contract was for a 30-year duration and included an opt-out element. Problems arose as soon as it was introduced, as people became wary of selling the benefits obtained from an ecosystem service they did not understand.

Two additional challenges were the 30-year timescale required by REDD+ and the resemblance of the contracts to those for the purchase of land. The 30-year duration caused concerns amongst village leaders over access to the forest reserves in a context of increasing demographic pressure. In the latter case the text of the contracts stated explicitly that the land and the forest remained the community's property, but the inclusion of a map suggested otherwise to people with low literacy. This issue was particularly controversial in light of recent negative experiences with a biofuels company (Mpingo Conservation and Development Initiative staff member, pers. comm., 2014). It was therefore decided to postpone discussions on carbon contracting until it becomes clear how much revenue will be made from carbon offsets, and exactly when sales can begin.

The Mpingo Conservation and Development Initiative has also begun developing general revenue-sharing agreements with communities (covering both timber and carbon), with the aim of the villages becoming financially self-sufficient, thus delivering one of the key features of REDD+: independence from donor funding. Villages have already indicated their readiness to move to such a system, with the two highest-earning villages in 2013 voluntarily contributing $5 \%$ of revenues earned from timber sales to the Mpingo Conservation and Development Initiative, although this percentage will need to rise for the Initiative to cover its costs. In the case of carbon offsets, which are more complex and harder for communities to market, communities may be open to a simple three-way split of revenue; for example, a third to the village, a third to the Mpingo Conservation and Development Initiative and a third to an intermediary to cover sales and marketing costs (including taxes).

\section{Discussion}

We set out to identify the causes of forest fires, and the existing knowledge of the early burning process and its potential impacts on livelihoods, particularly as a future source of carbon revenues. The impact of fire on a landscape depends on the timing and frequency of burning and on the availability of inflammable biomass. Complete protection of a forest for a number of years leads to an accumulation of fuel, which is more detrimental to tree biomass if a fire occurs; thus a fire management regime is necessary for the forest to thrive (Katani et al., 2015). The REDD+ project of the Mpingo Conservation and Development Initiative, which combines participatory forest management efforts with a fire management plan, can potentially generate lasting 
changes, with positive effects such as increased income and improved governance (Khatun et al., 2015).

The participatory early burning approach places rural communities at the centre of forest management activities and aligns with the interests of the majority of local people. Consistent with standard critiques of top-down conservation approaches (Phelps et al., 2010; Sodhi et al., 2011) our analysis shows the importance of sensitivity to local socioeconomic considerations when planning REDD+ projects, treating local people as strategic partners in conservation and climate mitigation efforts rather than culprits of biodiversity loss and climate change. Participatory forest management has translated into new village by-laws, newly demarcated village forests and increased revenue from sustainably managed timber. It also leverages REDD+ and the existence of voluntary carbon markets as institutional reference frameworks to generate potential additional financial value from early burning activities.

Social exclusion has not been deliberate but is a product of existing spatial discrimination, with households in outlying subvillages being less likely to benefit, and the fact that project management at this early, trial stage was principally ad hoc and did not seek to ensure fairness in internal governance processes and the selection of participants in early burning activities. Early burning has offered opportunities for some individuals to participate and earn money but there has been animosity among those excluded. Instituting a rotational system through which all households take part in early burning activities at some time could reduce conflict between community members.

Conflicts may yet arise between the Mpingo Conservation and Development Initiative, local people and other parties over who should be entitled to such revenues and how much each party should benefit (Corbera et al., 2011). Our findings raise concern about the poorest sector of the communities, as they were more likely to lack information, did not participate and were largely excluded from the early burning process. Most women interviewed lacked even basic knowledge of REDD+ activities unless they were involved in the relevant committee. Effective participation is necessary to ensure that REDD+ contributes to income diversification in communities (Katani et al., 2015), and therefore a more structured approach to early burning, with well-publicized advance planning and targeting all community members, could make a significant difference for both ethical and practical reasons: ethical because people need to understand that early burning activities serve both ecological and carbon trading purposes, and practical because poor understanding of carbon offsetting can lead to misunderstandings if carbon savings are ever realized and commercialized. Communities vary structurally and socially, and project managers need to target their efforts in awareness raising and training appropriately to ensure the broadest participation in both participatory forest management and REDD+ activities.
Hunting is difficult to control, and prosecuting illegal hunters is politically sensitive if poaching represents a significant share of their families' subsistence income. Encroachment by hunting concession holders into forests located around wildlife and game reserves is difficult to contest because such holders are well connected politically and pay high fees to the government (Benjaminsen et al., 2013). This suggests that local people will face significant challenges in attempting to defend collectively owned lands from the encroachment of more powerful stakeholders, as has been identified by other researchers (e.g. Dokken et al., 2014, in relation to enforcement of land tenure). Hence the successful development of early burning activities will depend to some degree on steering honest discussions and diplomacy beyond the project boundaries, involving powerful stakeholders that often operate quasi-legally. Increased state oversight and enforcement of common property rights, coupled with increasing staff and resources, may be an important complementary element in reducing the number of illegal activities that could hamper the success of REDD+ projects.

It is critical that participatory forest management results in a flow of economic benefits that are shared equitably at village level and can empower community members to take more decisive and legitimate action against activities, including hunting, that contravene project efforts, as well as mitigate the dissatisfaction with collective benefit-sharing that often underpins the motivations of local people to $\log$ or poach in common forests (Nielsen \& Meilby, 2013).

There are a number of lessons from this study that contribute to the emerging discussions on REDD+ implementation. Firstly, in addressing alternative causes of forest degradation, REDD+ pilot schemes may have to develop their own carbon accounting methodology to fit the reality of complex social-ecological systems while also taking into account market demands for transparently robust claims of carbon impacts. Secondly, we have shown that the Mpingo Conservation and Development Initiative, like any conservation and development organization, is pursuing its activities in a social context where there are inequalities in access to natural resources, income opportunities and availability of political information. These inequalities can undermine project efforts unless they are grounded in detailed knowledge of local livelihoods and village politics.

There are many issues that require further research and caution if the poorest communities are to benefit from REDD+. The success of activities such as fire management relies on the adaptive capacity of both project developers and participants, which in turn depends on evolving scientific and technical knowledge as well as socio-economic and political dynamics at regional and local scales. The committed involvement of local facilitators remains vital in ensuring the flow of information between local communities and international policy processes so that livelihoods are not compromised in the near- and long-term under REDD+ initiatives. 


\section{Acknowledgements}

We thank the residents of the study villages for their time and hospitality, and the staff of the Mpingo Conservation and Development Initiative, who made this work possible. We thank Adrian Martin for his guidance during fieldwork and his insightful comments on this article, and Marta Borrós Vendrell for her help with the figures. KK and EC acknowledge the financial support of Juan de la Cierva (JdC-2011-11205) and Ramón y Cajal research programme fellowships (RYC-2010-07183), respectively.

\section{References}

Aragão, L.E.O.C. \& ShimabukURo, Y.E. (2010) The incidence of fire in Amazonian forests with implications for REDD. Science, 328, $1275-1278$.

Barlow, J., Parry, L., Gardner, T.A., Ferreira, J., Aragão, L.E.O.C., CARMENTA, R. et al. (2012) The critical importance of considering fire in REDD+ programs. Biological Conservation, 154, 1-8.

Benjaminsen, T.A., Goldman, M.J., Minwary, M.Y. \& Maganga, F.P. (2013) Wildlife management in Tanzania: State control, rent seeking and community resistance. Development and Change, 44, 1087-1109.

Bowers, S. \& Williams, M. (2013) GapFire. The University of Edinburgh, UK. Http://www.geos.ed.ac.uk/gcel/gapfire.html [accessed 8 March 2016].

Bozmoski, A.S. \& Hultman, N.E. (2010) Participant perceptions of risk and benefit in carbon forestry: evidence from central Tanzania. The Journal of Environment and Development, 19, 4-27.

Burgess, N.D., Bahane, B., Clairs, T., Danielsen, F., Dalsgaard, S., FUnder, M. et al. (2010) Getting ready for REDD+ in Tanzania: a case study of progress and challenges. Oryx, 44, 339-351.

Corbera, E., Estrada, M., May, P., Navarro, G. \& Pacheco, P. (2011) Rights to land, forests and carbon in REDD+: insights from Mexico, Brazil and Costa Rica. Forests, 2, 301-342.

Corbera, E., Martin, A., Villasenor, A. \& Springate-Baginski, O. (2015) MCDI REDD Project: Combining REDD, PFM and FSC Certification in SE Tanzania. An Analysis of Livelihood Impacts Through Household Panel Data (2011-2014). Universitat Autònoma de Barcelona, Spain, \& University of East Anglia, UK.

Dokken, T., Caplow, S., Angelsen, A. \& Sunderlin, W.D. (2014) Tenure issues in REDD+ pilot project sites in Tanzania. Forests, 5 , 234-255.

Fense, J. (2012) Forest Carbon Project Feasibility Assessment of the MCDI Grouped REDD Project on Fire Management in Village Land Forest Reserves, Kilwa District, Tanzania. Unpublished report by LTS and Value for Nature, consulting for MCDI.

Fense, J. \& BAlL, S. (2014) Avoiding Degradation through Fire Management. VCS project description template version 3. Verified Carbon Standard, Washington, DC, USA.

Forsyth, T. (2014) Public concerns about transboundary haze: a comparison of Indonesia, Singapore, and Malaysia. Global Environmental Change, 25, 76-86.

Haines, T.K., Martinez, J. \& Cleaves, D.A. (1998) Influences on prescribed burning activity in the United States national forest system. International Forest Fire News, 19, 43-46.

Katani, J.Z., Mustalahti, I., Mukama, K. \& Zahabu, E. (2015) Participatory forest carbon assessment in south-eastern Tanzania: experiences, costs and implications for REDD+ initiatives. Oryx, http://dx.doi.org/10.1017/Soo30605315000174.
Khatun, K., Valdes, P.J., Knorr, W. \& Chaturvedi, R.K. (2010) Assessing the mitigation potential of forestry activities in a changing climate: a case study for Karnataka. Forest Policy and Economics, 12, 277-286.

Khatun, K., Gross-Camp, N., Corbera, E., Martin, A., Ball, S.M. J. \& Massao, G. (2015) When Participatory Forest Management makes money: insights from Tanzania on governance, benefit sharing, and implications for REDD+. Environment and Planning A, 47, 2097-2112.

KulL, C.A. (2002) Madagascar aflame: landscape burning as peasant protest, resistance, or a resource management tool? Political Geography, 21, 927-953.

KUlL, C.A. \& LARIS, P. (2009) Fire ecology and fire politics in Mali and Madagascar. In Tropical Fire Ecology: Climate Change, Land Use, and Ecosystem Dynamics (ed. M.A. Cochrane), pp. 171-226. Springer-Praxis, Heidelberg, Germany.

LARIS, P. (2011) Humanizing savanna biogeography: linking human practices with ecological patterns in a frequently burned savanna of southern Mali. Annals of the Association of American Geographers, 101, 1067-1088.

Laris, P., Caillault, S., Dadashi, S. \& Jo, A. (2015) The human ecology and geography of burning in an unstable savanna environment. Journal of Ethnobiology, 35, 111-139.

Minang, P.A. \& van Noordwijk, M. (2013) Design challenges for achieving reduced emissions from deforestation and forest degradation through conservation: leveraging multiple paradigms at the tropical forest margins. Land Use Policy, 31, 61-70.

Miy a, M., B All, S.M.J. \& Nelson, F.D. (2012) Drivers of Deforestation and Forest Degradation in Kilwa District. Mpingo Conservation and Development Initiative, Kilwa Masoko, Tanzania.

Müller, D., Suess, S., Hoffmann, A.A. \& Buchholz, G. (2013) The value of satellite-based active fire data for monitoring, reporting and verification of REDD+ in the Lao PDR. Human Ecology, 41, 7-20.

National Bureau of Statistics (2013) 2012 Population and Housing Census: Population Distribution by Administrative Areas. National Bureau of Statistics, Dar es Salaam, Tanzania.

Nielsen, M.R. \& Meilby, H. (2013) Determinants of compliance with hunting regulations under Joint Forest Management in Tanzania. South African Journal of Wildlife Research, 43, 120-137.

Peskett, L., Schreckenberg, K. \& Brown, J. (2011) Institutional approaches for carbon financing in the forest sector: learning lessons for REDD+ from forest carbon projects in Uganda. Environmental Science \& Policy, 14, 216-229.

Phelps, J., Webb, E.L. \& Agrawal, A. (2010) Does REDD+ threaten to recentralize forest governance? Science, 328, 312-313.

Russell-Smith, J., Monagle, C., Jacobsohn, M., Beatty, R.L., Bilbao, B., Millán, A. et al. (2013) Can savanna burning projects deliver measurable greenhouse emissions reductions and sustainable livelihood opportunities in fire-prone settings? Climatic Change, http://dx.doi.org/10.1007/s10584-013-0910-5.

Ryan, C.M. \& Williams, M. (2011) How does fire intensity and frequency affect miombo woodland tree populations and biomass? Ecological Applications, 21, 48-6o.

Sodhi, N.S., Butler, R., Laurance, W.F. \& Gibson, L. (2011) Conservation successes at micro-, meso- and macroscales. Trends in Ecology \& Evolution, 26, 585-594.

URT (United Republic of Tanzania) (2007) Prime Minister's Office, Information about Lindi Region, Kilwa District. Http://lindi. go.tz/lindi/lindi-rural/ [accessed 13 April 2016].

Van Lear, D.H., Carroll, W.D., Kapeluck, P.R. \& Johnson, R. (2005) History and restoration of the longleaf pine-grassland ecosystem: implications for species at risk. Forest Ecology and Management, 211, 150-165. 


\section{Biographical sketches}

KAYSARA KHATUN has worked in the private, NGO and academic sectors in the fields of climate change policy, land use and natural resource management. Her work reflects a keen interest in policy formation and implementation across scales for development and poverty reduction, notably in the context of forestry. EsTEVE CORBERA's work focuses on the governance of land-use management options for climate mitigation across scales. STEVE BALL founded the Mpingo Conservation \& Development Initiative in 1995. He is now pursuing his interests in a holistic approach to environmentally friendly rural development in Tanzania. 